UDC 338.1

N. Pysar ${ }^{1}$, Cand. Sc. (Econ.), Assoc. Prof., orcid.org/0000-0003-2656-7323,

V. Dergachova ${ }^{2}$, Dr. Sc. (Econ.), Prof., orcid.org/0000-0003-0317-8675,

O. Kyvliuk ${ }^{3}$, Dr. Sc. (Ph.), Prof.,

orcid.org/0000-0002-7900-9299,

D. Svyrydenko ${ }^{3}$, Dr. Sc. (Ph.), Assoc. Prof., orcid.org/0000-0001-6126-1747
DOI: $10.29202 /$ nvngu/2018-5/20

1 - Vasyl Stefanyk Precarpathian National University, Ivano-

Frankivsk, Ukraine, e-mail: diserdiser72@gmail.com

2 - Igor Sikorsky Kyiv Polytechnic Institute, Kyiv, Ukraine, e-mail: dergacheva.viktoria@gmail.com

3 - National Pedagogical Dragomanov University, Kyiv, Ukraine, e-mail: panyolga@ukr.net; denis_sviridenko@ukr.net

\title{
STRATEGIES FOR DEVELOPMENT OF UKRAINIAN ENERGY MARKET UNDER CONDITIONS OF GEOPOLITICAL CHALLENGES
}

Purpose. Taking into account the absence of an accurate estimate of Ukrainian economic system losses under the conditions of geopolitical challenges, the authors set the goal to carry out an analysis and assess the loss of real gross domestic product (GDP) of Ukraine by regions and determine the economic potential of Ukrainian energy market for overcoming the decrease in Ukraine's real GDP in the aspect of the developed scenario variants of strategic development of "New energy" economy cluster.

Methodology. The authors used systematic and analytical methods, modeling method, as well as foresight research approaches aimed at developing strategic variants of sustainable growth and business economic system development. Modern hybrid theory approaches also formed the theoretical framework of the study.

Findings. The research succeeded in substantiating the economic potential of the energy market to solve the problems of Ukrainian economic system development under the conditions of geopolitical challenges. It is shown that the lack of theoretical developments in estimation of real GDP losses and the lack of practical implementation of valuation indicators in management practice reduce the efficiency of solutions in the management of transformational processes in the economy. Possibilities of increasing budget revenues to overcome current losses of real GDP caused by the armed conflict in the East of Ukraine have been demonstrated against the background of opportunities for increasing the efficiency of implementation of energy market development strategies. The proposed action plan, based on scenario assessments of the potential for the region development, can be used by practitioners at the state level, as well as by different groups of stakeholders in the context of development and practical implementation of social and economic development strategies.

Originality. For the first time in the national discourse of management, the potential of the concept of "resource losses of GDP" has been investigated for overcoming global and local (national) contradictions in social and economic development, deepened by the challenges of geopolitical nature. The necessity of practical implementation of the methodology of GDP loss estimation and improvement of the methodology of its calculation has been revealed. The level of the real GDP in the regions of Ukraine has been demonstrated. Foresight research methodology was used to determine the potential of Ukrainian energy market development. Possibilities of implementation of the strategy of economic development of Ukraine, increase in national (in particular, energy) security of Ukraine are offered.

Practical value. The obtained results can serve as a benchmark for managing the transformational processes of the domestic economy, for modernizing the energy market under the conditions of fuel and energy resource constraints, in particular, when developing scenarios for integrating the energy market of Ukraine into the European energy space and ensuring state policy under the conditions of violated territorial integrity of Ukraine.

Keywords: gross domestic product (GDP), economic losses, GDP deflator, dynamics, energy market, strategy, geopolitics

Introduction. As a result of the armed hostilities in the East of Ukraine and the annexation of the Crimea, the urgency and necessity of restoration of GDP losses of Ukraine and the study of ways to increase the economic potential of the national economic system have become acute and necessary. The resource losses of the dominant mining industry in Donetsk and Luhansk regions shattered one of the existing reserves for improving the efficiency of any country's economy - energy security of Ukraine. Ukrainian enterprises, such as metallurgical plants and power stations, will not be able to receive resources from the Donbas, including coking coal, and are forced to seek other sources of fuel and energy supplies. Therefore, the problem of restoring the economic poten-

(C) Pysar N., Dergachova V., Kyvliuk O., Svyrydenko D., 2018 tial of the economic system of Donetsk and Luhansk regions of Ukraine and integral implementation of the economy of these regions into the economic organism of Ukraine requires an immediate solution and a special study of GDP, as there is no statistical information on the losses incurred as a result of the military geopolitical challenges of a hybrid nature. Since the characteristics of the interregional economic potential with the available means of production, natural, labor, scientific and technical resources are uneven due to the peculiarities of their historical development and various industrial and economic specializations, the contribution of various regions of Ukraine into its GDP is also uneven. Under such conditions, it is more interesting to assess the diversification of the contribution of different regions of Ukraine into the total loss of its GDP caused by the mil- 
itary conflict. The result of this study may be useful for improving the management of both the energy security of Ukraine and the economy as a whole.

Analysis of the recent research. Well-known researchers of this problem, namely N. Fatiukha and T. Makushina analyzed GDP dynamics and factors; however, it would be advisable to take a much larger time frame of the studied period, which would allow seeing GDP losses in the analysis of its indicators [1]. As an alternative, S. Moroz analyzed the current state and dynamics of the gross domestic product and population of Ukraine over the last twelve years and built a correlation model of gross domestic product dependence on the population size, the number of employed population and the number of the unemployed [2]. Economic losses of the national economy of Ukraine were calculated taking into account the effects of unemployment and using the correlation model. Boyko Y. and Hapak N. analyzed the dynamics of gross domestic product and price indices in Ukraine during 2010-2016. They determined their tendencies and characterized the shadow economy and its level in Ukraine within these seven years, but they did not determine the level of GDP losses [3]. Koriagina T. and others show the interdependence of changes in GDP and other macroeconomic indicators and prove that a negative net export indicator negatively affects GDP [4]. Kiosieva A. found that the GDP of Ukraine directly depends on the volume of industrial production in the country and the volume of retail trade turnover [5]. On the basis of research by L.Akinfiiev and L. Bielozorov, it is proved that for achievement of macroeconomic stabilization it is necessary to make three basic steps: 1) to lower inflation; 2) to stop the fall of production and start its recovery; 3 ) to repay the external debt of the state [6].

Besides, a group of scientists led by M.Zgurovskyi [7], using the methodology of scenario planning and SWOT analysis, clarified eight scenarios of Ukraine's social and economic development until 2030 (including). The authors prove that domestic power industry, mining and processing industries suffered the greatest losses as the bulk of their production capacities are concentrated on the temporarily uncontrolled part of the Donbas.

Proceeding from the understanding of the hybrid armed conflict as a modern social and cultural phenomenon, which uses artificially created internal contradictions in the country, towards which the hybrid military aggression is directed, we find the works by S. Klepko [8], D. Svyrydenko [9], O. Bazaluk [10] really helpful. They reveal the mechanisms for hybrid military aggression implementation through key public institutions and mechanisms such as education, economics, and others. Challenges to management systems in the context of complex modernization processes were researched by M. Hladchenko [11], S. Rudenko [12], and others.

Taking into account analysis of publications on the above-mentioned problems, it is clear that the study of real GDP, in terms of estimating the losses of the economic system of Ukraine under the conditions of the challenges of the current geopolitical confrontation, has not been given sufficient attention. The authors do not propose a methodology for calculating GDP losses, which distinguishes our research from the previous ones, and allows us to obtain precise information for management measures in terms of determining strategic directions of the economic system of Ukraine through the prism of enhancing its energy security, the level of which has decreased under the conditions of the military conflict. Thus, there is a gap between the theoretical statement of the problem of restoration of the economic potential of the economic system of Ukraine and the practical issues of substantiation of the mechanisms for its solution.

Objectives of the article. Within the article the authors' strategy for the development of the Ukrainian energy market under the conditions of the armed conflict will be proposed. To do this, it is necessary to conceptualize the specifics of the challenges of the modern geopolitical conflict to the energy market of Ukraine, to give an explanation of the category of "resource losses of GDP", to determine the nature and list of losses of the economic potential of Ukraine's GDP, which arose as a result of hostilities in the East of Ukraine and annexation of the Crimea; to assess these losses, as well as to propose the main goals of the strategy of the energy market development and increase the level of energy security of Ukraine.

Presentation of the main research. Economic dynamics in Ukraine are controversial. Since the beginning of the 2000s, Ukraine has experienced two financial and economic downturns, namely in 2009 and 2014, which has led to a deep recession of key macroeconomic indicators. Inclusion of Ukraine in the process of geopolitical confrontation has aggravated the crisis in the domestic economy. This decline is characterized by the researchers of transition processes as a transformation decline, or a transformational crisis. In contrast to the cyclical downturn, which is typical for the dynamics of the market economy, the transformation decline is a decline of a particular kind caused by the processes of transition from one economic system to another. In this case, there is a change in social and economic relations, a change in the structure of the economy, and, as a consequence, a reduction (to almost complete disappearance) of certain industries and types of economic activity and emergence of others that did not exist in the previous economic system. The experience of most countries that had this transition to the market system confirms the hypothesis of a transformation recession as an integral element of the transition process. For example, China also implemented a program of economic transformation, but progressively, in an evolutionary way, and it did not only avoid the economic downturn, but maintained a strong GDP growth rate by almost 10 times. In order to obtain an initial estimate of the losses incurred during the transformation of the economy, it is necessary to use a traditional macroeconomic indicator, such as the volume of real GDP. The purpose in this case is not assessment of the losses of welfare, income, changes in the structure of the economy, and so forth, as much as the assessment of lost opportunities for national economic growth and development as a result of the loss of historical time. The negative indicator of real GDP (Tables 1, 2) indicates the lost potential that could 
be used to achieve various goals: both for the further increase in the population's consumption, and for comprehensive modernization of the economy, restoration of industrial potential, upgrading of fixed assets. The indicator of nominal GDP at actual prices in 2010 converted to the level of the previous year (Table 1) was taken for analysis. In addition, analysis of real GDP indicator in relation to the level of 2005 (\%) was performed. Thus, the study characterizes to what extent GDP growth is a real growth in production, rather than rising prices. The depth of GDP fall (Figure) shows the amount of GDP reduction compared to the base year at the lower point of the transformation decline. Thus, in Ukraine, real GDP in 2016 amounted to $+14 \%$ of the level of $2005-(+19 \%)$. Accordingly, the depth of the decline from 2004 to 2016 was $5 \%$. The period from 2004 to 2016 was characterized by an uneven decline in real GDP, since real GDP grew from 2006 to 2008 and from 2010 to 2013, but the losses of its fall in 2009 and 2014 required significant compensations of the growing GDP in the coming years. The calculation of accumulated GDP losses, based on the methodological principle of lost profits, can be formulated as the total value of deviations of actual real GDP from the base amount of GDP in each period during which such a deviation occurred. At the same time, two options are proposed for calculating the basic amount of GDP, for which the calculation is made (and, accordingly, the basic trajectory of economic dynamics).

The first variant (a static one) involves maintaining a constant value of the base GDP. Consequently, in Table 1 it will be the indicator of real GDP in 2004. This is the easiest way to calculate the accumulated GDP loss and it will generally give the lower bound for estimating such losses.

The second option (dynamic) involves a preliminary analysis of the economic dynamics of the country in the previous transformation period. As a result, the base growth trend can be obtained on the basis of calculating the average growth rate of the real GDP of the country in the specified period, which is then extrapolated into the future. In this case, the base amount of GDP, for which the calculation of accumulated losses is made, becomes a variable amount in accordance with the received base growth trend. The calculation of losses in the second option, in general, gives a higher rating, since the economy should come not to the stationary level of GDP of the base year, but on the trajectory of the base trend of growth.

The indicator of accumulated GDP losses can be obtained by summing up the indicators of deviation of real GDP from the level of real GDP in the base year, both during the period of the transformation decline and in the period during which the recovery growth took place.

Figure shows the dynamics of real GDP of Ukraine for the period of 2004-2016 in \% with reference to the level of 2004. Accumulated GDP losses are equal to the area of the figure, bounded at the top with the line of 100 $\%$, and at the bottom with the values of GDP during the period of recession and recovery, that is, 2009 and 2013-2015 (Figure). Having made calculations based on the data [13], we get the value of accumulated losses of GDP of Ukraine for the period of 2005-2016 in the amount of $35 \%$. Due to the transformational downturn and the need to overcome it in the form of formation and growth, Ukraine lost $5 \%$ of GDP, although nominal GDP of Ukraine is 5.4 times higher than in 2005. At the same time, Ukrainian economy worked to reduce its accumulated costs at the expense of the economic growth of 2007-2008 and 2011-2013.

Thus, in addition to the recovery growth, which is necessary for the restoration of output at the pre-crisis level (in this case at the level of 2005), the period of compensatory growth is needed - the economic growth which is necessary to eliminate the accumulated losses

Table 1

Dynamics of nominal and real GDP of Ukraine

\begin{tabular}{|c|c|c|c|c|c|c|}
\hline Years & $\begin{array}{l}\text { Nominal GDP } \\
\text { of Ukraine, } \\
\text { million, UAH }\end{array}$ & $\begin{array}{l}\text { Deflator } \\
\text { of GDP } \\
\text { of kraine }\end{array}$ & $\begin{array}{c}\text { Changes in the deflator } \\
\text { with reference to the } \\
\text { base year }\end{array}$ & $\begin{array}{l}\text { Real GDP, } \\
\text { million, } \\
\text { UAH }\end{array}$ & $\begin{array}{c}\text { Changes in real GDP } \\
\text { with reference to the } \\
\text { previous year, } \%\end{array}$ & $\begin{array}{c}\text { Change in real GDP } \\
\text { with reference } \\
\text { to } 2005, \%\end{array}$ \\
\hline 2004 & 345113.00 & 40.0 & 0.400 & 862782.50 & & \\
\hline 2005 & 441452.00 & 43.0 & 0.430 & 1026632.56 & +19 & \\
\hline 2006 & 544153.00 & 49.4 & 0.494 & 1101524.29 & +7 & +7 \\
\hline 2007 & 720731.00 & 60.6 & 0.606 & 1189325.08 & +8 & +16 \\
\hline 2008 & 948056.00 & 78.0 & 0.780 & 1215456.41 & +2 & +18 \\
\hline 2009 & 913345.00 & 88.2 & 0.882 & 1035538.55 & -15 & +1 \\
\hline 2010 & 1082569.00 & 100.0 & 1.000 & 1082569.00 & +5 & +5 \\
\hline 2011 & 1302079.00 & 114.2 & 1.142 & 1140174.26 & +5 & +11 \\
\hline 2012 & 1459096.00 & 123.1 & 1.231 & 1185293.26 & +4 & +15 \\
\hline 2013 & 1522657.00 & 128.4 & 1.284 & 1185869.94 & 0 & +16 \\
\hline 2014 & 1586915.00 & 148.9 & 1.489 & 1065758.90 & -11 & +4 \\
\hline 2015 & 1988544.00 & 206.7 & 2.067 & 962043.54 & -10 & -6 \\
\hline 2016 & 2385367.00 & 242.2 & 2.422 & 984874.90 & +2 & -4 \\
\hline
\end{tabular}


Table 2

Resource losses of the economic system of Ukraine

\begin{tabular}{|c|c|c|c|c|c|}
\hline Indicator Region & $\begin{array}{c}\text { Real GRP } \\
\text { in 2005, } \\
\text { million, UAH }\end{array}$ & $+/-\underset{\%}{\text { GRP }}$ & $\begin{array}{c}\text { Amount } \\
\text { of revenues/losses } \\
\text { of real GRP in } 2010 \\
\text { prices, million, UAH }\end{array}$ & $\begin{array}{c}\text { Amount } \\
\text { of revenues/losses } \\
\text { of real GRP in } 2016 \\
\text { prices, million, UAH }\end{array}$ & $\begin{array}{c}\text { Real GRP, 2016, } \\
\text { million, UAH }\end{array}$ \\
\hline Luhansk & 45851.16 & -71.8 & -32921.13 & -79669.15 & 12946.33 \\
\hline Donetsk & 134986.05 & -58.0 & -78291.91 & -189466.41 & 56771.26 \\
\hline Zakarpattia & 15581.40 & -14.0 & -2181.40 & -5278.98 & 13373.25 \\
\hline Chernivtsi & 9846.51 & -10.0 & -984.65 & -2382.86 & 8769.20 \\
\hline Zaporizhzhia & 46437.21 & -7.2 & -3343.48 & -8091.22 & 43073.08 \\
\hline Ivano-Frankivsk & 22376.74 & -5.0 & -1118.84 & -2707.59 & 21223.78 \\
\hline Volyn & 15239.53 & -3.5 & -533.38 & -1290.79 & 14758.05 \\
\hline ARC & 29879.07 & 0.0 & 0.00 & 0.00 & 0.00 \\
\hline The city of Sevastopol & 6565.12 & 0.0 & 0.00 & 0.00 & 0.00 \\
\hline Rivne & 16890.70 & 0.1 & 16.89 & 40.88 & 16296.04 \\
\hline Chernihiv & 17737.21 & 1.0 & 177.37 & 429.24 & 17903.39 \\
\hline Odesa & 48283.72 & 2.5 & 1207.09 & 2921.17 & 49463.25 \\
\hline Sumy & 18662.79 & 2.5 & 466.57 & 1129.10 & 19111.07 \\
\hline Kherson & 15044.19 & 5.0 & 752.21 & 1820.35 & 15996.28 \\
\hline Dnipropetrovsk & 95876.74 & 5.3 & 5081.47 & 12297.15 & 100940.55 \\
\hline Ternopil & 11946.51 & 7.0 & 836.26 & 2023.74 & 12829.07 \\
\hline Kharkiv & 59576.74 & 7.0 & 4170.37 & 10092.30 & 63943.44 \\
\hline Mykolaiv & 22216.28 & 8.0 & 1777.30 & 4301.07 & 23870.77 \\
\hline Khmelnytskyi & 18506.98 & 9.0 & 1665.63 & 4030.82 & 20173.00 \\
\hline Poltava & 42090.70 & 14.2 & 5976.88 & 14464.05 & 48006.61 \\
\hline Zhytomyr & 17279.07 & 15.0 & 2591.86 & 6272.30 & 19784.89 \\
\hline Cherkasy & 20962.79 & 15.0 & 3144.42 & 7609.49 & 24530.14 \\
\hline Lviv & 39981.40 & 18.5 & 7396.56 & 17899.67 & 47416.18 \\
\hline Kirovohrad & 15993.02 & 19.0 & 3038.67 & 7353.59 & 19001.24 \\
\hline The city of Kyiv & 179358.14 & 28.5 & 51117.07 & 123703.31 & 230858.79 \\
\hline Vinnytsia & 23737.21 & 29.4 & 6978.74 & 16888.55 & 30722.96 \\
\hline Kyiv & 35725.58 & 48.5 & 17326.91 & 41931.11 & 53112.30 \\
\hline Ukraine & 1026632.56 & -4.1 & -41989.27 & -101614.04 & 984874.90 \\
\hline
\end{tabular}

of the transformation decline. In other words, the accumulated GDP losses are zeroed as a result of compensatory growth.

However, the situation was much worse with the compensatory growth. The recovery growth in Ukraine compensates for the growth at the turn of 2006-2008, but in 2009 the economic crisis erupted and the period of compensatory growth was interrupted. In 2010-2012 there was a recovery growth in Ukraine relative to the level of GDP before the crisis, i.e. in 2009. Since 2012, the slowdown of the Ukrainian economy, which declined in 2013, has played a role in slowing down the accumulated losses. The economic downturn in 2014-2016 significantly complicates the possibility of further compensatory growth. According to the calculations, in order to overcome the loss of GDP in 2014-2015 (-20\%) by 2020 , annual growth of real GDP should be at least $8 \%$.
The calculation of accumulated losses on a dynamic basis gives a figure of $5 \%$ of GDP in 2005. However, if you calculate the average actual growth rate of real GDP

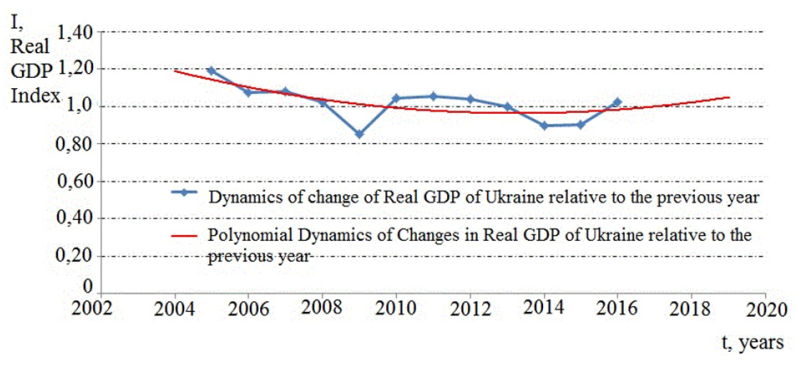

Fig. Retrospective analysis and forecasting of changes in the real GDP of Ukraine with reference to the previous year 
of Ukraine for the period of 2004-2016, then it will equal $2 \%$. For example, in order to reach the specified trajectory of GDP level of 2008, for 10 years (2016), the real GDP growth rate of Ukraine, starting from 2016, should be at least $+2 \%$. Continuation of the economic downturn in 2016 complicates the achievement of the basic growth trend in the near term. The line of the basic trend of GDP growth of the country that would have taken place while maintaining its average annual growth rate of GDP for the previous period has a downward inclination (Figure).

The largest losses were experienced in the processing, mining and energy industries, whose bulk of production capacity was concentrated on the temporarily uncontrolled part of the Donbas. The structural and resource losses caused by this alienation can be divided into two categories: the first one is the loss of the territories, the second one is the irreversible losses of the economic potential caused by the destruction of the economic and industrial sector (enterprises, factories) that were not transferred to the territory of Ukraine at the initial stages of the armed conflict [7].

The change in the real sector part of the economy of Donetsk and Luhansk regions in the structure of real GDP of Ukraine was the result of a fall in real GDP of Ukraine, in the structure of industry of Ukraine. Mining industry and the development of quarries reduced the growth rates of industrial production in 2014-2015 by 13 and $14 \%$, respectively, the production of chemicals and chemical products, metallurgical production decreased by 14 and $16 \%$, respectively, during 2014-2015, while machine building fell by 20 and $14 \%$, respectively. In 2014, coal production in general declined by more than $22 \%$ compared with the previous year, including the coal of anthracite group - by one third [14]. In 2015, extraction decreased by $36.8 \%$ compared to 2014 . Due to the loss of resources, there is a significant decrease in the economic performance of the fuel and energy complex of Ukraine. Another strategically important industrial segment, which was almost entirely concentrated in the Donbas, is the extraction of metal ore, which has shrunk by 9.5 million tons over the past two years. Mining of salt, the amount of which is also the prerogative of Donetsk region [7], declined substantially during the defined period.

In order to understand how large the share of losses of the gross regional product (GRP) of the regions of the state is, it is necessary to estimate the ratio of the amount of GRP losses due to transformational changes in the economy under the conditions of geopolitical challenges, with official data on the size of the GRP. The results of the calculation of losses of the regions' GRP due to transformational changes in the economy and under conditions of geopolitical challenges allows us to conclude that there is a regional differentiation of the degree of damage of transformational changes and the current geopolitical situation for the country's economy. Donetsk region suffered the maximum economic loss due to the current transformational changes in the economy, although Luhansk region experienced the greatest changes in the economy and reduced the level of its own economy by as much as $70 \%$. The first thing to note is the wide range of values of the share of GRP losses of the regions of Ukraine. These results publicly show a significant spatial differentiation of Ukrainian economy.

In general, it can be noted that with the growth of the significance of the industrial energy potential, a specific region of Ukraine for the economy of the country, relative losses of the GRP under the conditions of the geopolitical conflict of hybrid nature are increasing, accounting for at least $20 \%$ of the domestic economic potential. Starting from the first days of hostilities, there was a reduction in the number of enterprises in the mining, metallurgical and machine-building complexes in Ukraine. About three quarters of coal mines in Ukraine are located in the temporarily uncontrolled territories, which, accordingly, affects the dynamics of output in the key sectors of heavy industry: "The losses of domestic metallurgical enterprises are estimated at about 40 billion UAH, including 25 billion UAH as lost profits from uderproduced products, 25 billion UAH as the cost of destroyed fixed assets. In machine building, the decrease in production amounted to $20.6 \%$; according to preliminary estimates, in 2014 the losses of the industry amounted to 10 billion UAH" [14].

The losses in the production of chemical products (mineral fertilizers, nitrogen compounds, and others), the center of which also included the regions of Donetsk and Luhansk regions, are equally significant: "In 2014 ammonia production in Ukraine decreased by $30.8 \%$, and the capacity for the production of mineral fertilizers actually lost $36 \%$. There was a danger of stopping the glass industry companies (now the capacity of glass production has been lost by $90 \%$ ), which in turn could lead to the stoppage of the enterprises of food production, baby food, medical products and drinks of various kinds" [14].

In the opinion of a number of authors, provided that new high-tech clusters are included in the Ukrainian economy, the budget deficit of Ukraine may decrease. Thus, the energy cluster in the structure of the future national economy for the medium-term (2020) and long-term (2030) perspectives can provide $5-8 \%$ of the total revenues to the budget, in the overall growth of the economy [7]. The presented matrix of the effects of strong and weak characteristics on the opportunities and threats for the development of the energy market indicates that strong characteristics can enhance (make more likely) opportunities and weaken (make less likely) threats, and, conversely, weak characteristics can weaken opportunities and increase threats [7].

Conclusions. Thus, a return to the trajectory of precrisis growth for at least a decade will require from Ukraine a sharp increase in industrial growth - no less than $8 \%$ annually by 2020 . The current growth model in Ukraine is not able to provide such a pace; therefore, the transition to a new market economy model is topical, including the purpose to compensate for the negative effects of the transition period and return to the pre-crisis trajectory of national economic growth and overcome the challenges of the Ukrainian economy under the conditions of the current geopolitical challenges.

Such a transition is impossible without a new industrialization in the country, restoration of industry (first of all - mining, oil refining and machine building), reach- 
ing the positive trend of natural population growth. In order to realize these trends of development of the energy cluster in Ukraine, systemic changes are needed in the Ukrainian economy, which, in particular, should include active industrial policy and state support. To eliminate the losses of the historical time of Ukraine, a transition to a new model of economic growth is required which is based on a progressive system of growth factors in contrast to the factors which used to determine economic growth of the former raw material model. The new model should rely on the approaches that minimize the possibility of using economic instruments in the implementation of geopolitical strategies of hybrid character. A differentiated assessment of the economic losses of the regions of Ukraine caused by the transformational changes in the economy and challenges of the geopolitical nature can serve as the basis for building the regional policy in the field of public administration and estimation of the level of national, in particular, energy security of Ukraine.

\section{References.}

1. Fatyukha, N. G. and Makushina, T.P., 2015. Analysis of Dynamics of GDP of Ukraine. Effective Economy [online], 12, Available at: <http://www.economy.nayka.com. ua/?op $=1 \& z=4634>$ [Accessed 21 November 2017].

2. Moroz, S. V., 2017. GDP as a criterion for assessing Ukraine's national security. Problems of the system approach in the economy [pdf], 6(62). Available at: <http:// psaejrnl.nau.in.ua/journal/6_62_1_2017_ukr/15.pdf $\rangle$ [Accessed 2 December 2017].

3. Boyko, Y. M. and Hapak, N. M., 2017. GDP of Ukraine: Level and trends of dynamics. Scientific Herald of the International Humanitarian University. Scientific Bulletin of the International Humanitarian University, 25(1), pp. 69-72.

4. Koryagina, T. V., Stasyuk, A. V. and Sosenkova, K. R., 2016. Dynamics of Ukraine's GDP and the impact of some components on its change. Young scientist. Economic sciences, 12(39), pp. 763-767.

5. Kioseva, I. A. and Kurova, T. G., 2016. Analysis of the gross domestic product of Ukraine. Bulletin of the Berdyansk University of Management and Business, 3(35), pp. 21-26.

6. Akinfiyeva, L.P. and Belosorova, L.S., 2014. Factor analysis of the dynamics and structure of Ukraine's GDP. Bulletin of Social and Economic Research, 1(52), pp. 93-98. 7. Zgurovsky, M.Z., 2016. Foresight and construction of the strategy of socio-economic development of Ukraine in the medium-term (until 2020) and long-term (until 2030) time horizons. Kyiv. NTUU "KPI".

8. Klepko, S., 2017. Pedagogy of Peace and Philosophy of War: the Search for Truth. Future Human Image, 7, pp. 46-49.

9. Svyrydenko, D., 2017. Divided Universities: The Postcolonial Experience of Contemporary Ukrainian Higher Education, Future Human Image, 7, pp. 128-135. 10. Bazaluk, O., Svyrydenko, D. and Terepyshchyi, S., 2017. Structural-functional models of integration and reintegration of Ukrainian educational landscape. Naukovyi Visnyk Natsionalnoho Hirnychoho Universytetu, 5, pp. 163-168.
11. Hladchenko, M., 2016. The organizational identity of Ukrainian universities as claimed through their mission statements. Tertiary Education and Management, 22(4), pp. 376-389. DOI: 10.1080/13583883.2016.1236144.

12. Rudenko, S., Sapenko, R., Bazaluk, O. and Tytarenko, V., 2018. Management features of international educational projects between universities of Poland and Ukraine. Naukovyi Visnyk Natsionalnoho Hirnychoho Universytetu, 2, pp. 142-147. DOI: 10.29202/nvngu/2018-2/21.

13. State Statistics Service of Ukraine. Statistical collections "Ukraine-2014”, “Ukraine-2015”, “Ukraine-2016”. Available at: <http://www.ukrstat.gov.ua> [Accessed 11 October 2017].

14. Evaluation of losses and mechanisms of reconstruction of the real sector of Ukrainian East economy. Analytical note [online]. Available at: < http://www.niss.gov. ua/public/File/2015_analit/realniy_sector.pdf> [Accessed 27 February 2018].

\section{Стратегії розвитку енергетичного ринку України в умовах геополітичних викликів}

\section{Н. Писар ${ }^{1}$, В. Дергачова ${ }^{2}$, О. Кивлюк ${ }^{3}$, Д. Свириденко ${ }^{3}$}

1 - Прикарпатський національний університет імені Василя Стефаника, м. Івано-Франківськ, Україна, е-mail: diserdiser72@gmail.com

2 - Національний технічний університет України „Київський політехнічний інститут імені Ігоря Сікорського“, м. Київ, Україна, e-mail: dergacheva.viktoria@gmail.com 3 - Національний педагогічний університет імені М.П.Драгоманова, м. Київ, Україна, e-mail: panyolga@ ukr.net; denis_sviridenko@ukr.net

Мета. За умови відсутності точної оцінки втрат господарюючої системи України в умовах геополітичних викликів, автори поставили собі за мету провести аналіз і дати оцінку втратам реального валового внутрішнього продукту (ВВП) України в регіональному розрізі та визначити економічний потенціал енергетичного ринку України для подолання падіння реального ВВП України в аспекті розроблених сценарних варіантів стратегічного розвитку кластеру економіки „Нова енергетика“.

Методика. Авторами були застосовані системний та аналітичний метод, метод моделювання, а також підходи форсайт-дослідження, метою яких є розробка стратегічних варіантів стійкого зростання й розвитку господарюючої економічної системи. Теоретичною рамкою дослідження також виступили підходи сучасної теорії гібридності.

Результати. У дослідженні вдалося обгрунтувати економічний потенціал енергетичного ринку для розв'язання проблем розвитку української господарюючої системи в умовах геополітичних викликів. Показано, що брак теоретичних розробок в оцінці втрат реального ВВП і практичної імплементації оціночних показників в управлінську практику знижує ефективність рішень в управлінні трансформаційними процесами економіки. На тлі можливостей підвищення ефективності реалізації стратегій розвитку енергетичного ринку продемонстровані можливості зростання доходів бюджету 
для подолання поточних втрат реального ВВП, ініційованих збройним конфліктом на Сході України. Запропонована програма дій, заснована на сценарних оцінках потенціалу для розвитку регіону, може використовуватися практиками на державному рівні, а також різними групами стейкхолдерів у контексті розробки та практичної реалізації стратегій соціально-економічного розвитку.

Наукова новизна. Уперше у вітчизняному дискурсі менеджменту був системно досліджений потенціал концепту „ресурсні втрати ВВП“ для розв'язання глобальних і локальних (національних) протиріч соціально-економічного розвитку, поглиблених викликами геополітичного характеру. Виявлена потреба практичної імплементації методології оцінки втрат ВВП й удосконалення методології його розрахунку. Продемонстровано рівень реального ВВП у розрізі регіонів України. Використана методологія форсайт-дослідження для визначення потенціалу розвитку енергетичного ринку України. Запропоновані можливості реалізації стратегії економічного розвитку України, підвищення рівня іiі національної (зокрема, енергетичної) безпеки.

Практична значимість. Отримані результати здатні постати орієнтиром в управлінні трансформаційними процесами вітчизняної економіки для модернізації енергетичного рику в умовах паливноенергетичних ресурсних обмежень, зокрема, при розробці сценаріїв інтеграції енергетичного ринку України у європейський енергетичний простір і забезпечення державної політики в умовах порушеної територіальної цілісності України.

Ключові слова: валовий внутрішній продукт (ВВП), економічні втрати, дефлятор ВВП, динамі$\kappa a$, енергетичний ринок, стратегія, геополітика

\section{Стратегии развития энергетического рынка Украины в условиях геополитических ВЫзовов}

\section{Н. Пысар ${ }^{1}$, В. Дергачёва ${ }^{2}$, О. Кивлюк ${ }^{3}$, Д. Свириденко}

1 - Прикарпатский национальный университет имени Василия Стефаника, г. Ивано-Франковск, Украина, e-mail: diserdiser72@gmail.com

2 - Национальный технический университет Украины „Киевский политехнический институт имени Игоря Сикорского“, г. Киев, Украина, e-mail: dergacheva.viktoria@ gmail.com

3 - Национальный педагогический университет имени М. П.Драгоманова, г. Киев, Украина, e-mail: panyolga@ ukr.net; denis_sviridenko@ukr.net

Цель. При отсутствии точной оценки потерь хозяйствующей системы Украины в условиях геополитических вызовов, авторы поставили перед собой цель провести анализ и дать оценку потерь реального валового внутреннего продукта (ВВП) Украины в региональном разрезе, и определить экономический потенциал энергетического рынка Украины для преодоления падения реального ВВП Украины в аспекте разработанных сценарных вариантов стратегического развития кластера экономики „Новая энергетика“.
Методика. Авторами были применены системный и аналитический метод, метод моделирования, а также подходы форсайт-исследования, целью которых является разработка стратегических вариантов устойчивого роста и развития хозяйствующей экономической системы. Теоретической рамкой исследования также выступили подходы современной теории гибридности.

Результаты. В исследовании удалось обосновать экономический потенциал энергетического рынка для решения проблем развития украинской хозяйствующей системы в условиях геополитических вызовов. Показано, что недостаток теоретических разработок в оценке потерь реального ВВП и практической имплементации оценочных показателей в управленческую практику снижает эффективность решений в управлении трансформационными процессами в экономике. На фоне возможностей повышения эффективности реализации стратегий развития энергетического рынка продемонстрированы возможности роста доходов бюджета для преодоления текущих потерь реального ВВП, инициированных вооруженным конфликтом на Востоке Украины. Сценарные оценки потенциала развития региона могут использоваться практиками на государственном уровне, а также различными группами стейкхолдеров в контексте разработки и дальнейшей реализации стратегий социальноэкономического развития.

Научная новизна. Впервые в отечественном дискурсе менеджмента был системно исследован потенциал концепта „ресурсные потери ВВП“ для решения глобальных и локальных (национальных) противоречий социально-экономического развития, усиленных вызовами геополитического характера. Выявлена потребность практической имплементации методологии оценки потерь ВВП и совершенствование методологии его расчета. Продемонстрирован уровень реального ВВП в разрезе регионов Украины. Использована методология форсайт-исследования для определения потенциала развития энергетического рынка Украины. Предложены возможности реализации стратегии экономического развития Украины, повышения уровня её национальной (в частности, энергетической) безопасности.

Практическая значимость. Полученные результаты способны предстать ориентиром в управлении трансформационными процессами отечественной экономики для модернизации энергетического рыка в условиях топливно-энергетических ресурсных ограничений, в частности, при разработке сценариев интеграции энергетического рынка Украины в европейское энергетическое пространство и обеспечение государственной политики в условиях нарушенной территориальной целостности Украины.

Ключевые слова: валовой внутренний продукт (ВВП), экономические потери, дефлятор ВВП, динамика, энергетический рынок, стратегия, геополитика

Рекомендовано до публікації докт. екон. наук С. В. Войтком. Дата надходження рукопису 09.07.17. 